\title{
The deep process of the collision structure in northern Tibet revealed from investigation of the deep seismic profiles
}

\author{
Gao Rui*, Li Qiusheng, Guan Ye, Li Pengwu and Bai J in \\ Institute of Geol ogy, Chinese Academy of Geol ogical Sciences, Beijing 100037, CHINA \\ *To whom correspondence should be addressed. E-mail: gaorui@cags.net.cn
}

In recent years, the crust and upper mantle structure of the northern Tibetan plateau has al ready attracted wide attention from geologiststhroughout the world. The collision generates not onlyin thesouthern Tibetan plateau butalso in thenorthern part. The Tarim basin as a continental block not only has been obstructingthecollision from the Indian continent, butalso may have been subducting beneath the Tibetan plateau and generating collision, butthescaleand deep process havenot been fully understood yet. Therefore, probingthe deep structure of the collision boundary in the northern Tibetan plateau is of special significance to comprehend the deep process of the intracontinent deformation caused by collision.

Since 1993, deep geophysical investigations have been carried out along the northern margin of Tibet across the basinand-range conjectures. They include several deep seismic reflection profiles, wide-angle reflection and refraction profiles as well as broadband regional observation. They revealed the lithospheric structure of the northern margin of the Tibetan plateau at different tectonic layers. Some profiles and interpretations in detail will be discussing in this paper.

(1) The reflection image of the southward Tarim block subduction at a steep angle was found both in theWest Kunlun (Gao et al. 2000) and Qilian profiles (Gao et al. 1995, 1999). In the Altyn profile, the shearing at a lithosphere scale constrains the subduction of the Tarim crust beneath the Tibetan plateau, but the Tarim mantle has already subducted beneath the plateau (Gao et al. 2001).

(2) M any groups of stronger reflections, dipping northwards under the west Kunlun M ts. and southwards under thesouthern margin of the Tarimbasin, constitutetheevidencefor thecollision between the Tarim basin and the Tibetan plateau (Gao etal. 2000, Kao et al. 2001). The image of reflection structure reveals theVshaped basin-and-rangecoupling relationship between thewest Kunlun Mts. and the Tarim basin on a lithosphere scale.

It should be particularly pointed out that a face-to-face collision pattern has not been found under the lithosphere of Tibetan plateau before. Based on the comparison of theface-tofacecompression model with the deep seismic reflection profile of the Indian continent subduction beneath the southern Tibet and the seismic research of subduction residuals of the Tethys oceanic crust found under Yarlungzangbo suture, the authors consider that the north-dipping reflection under thewest Kunlun Mts. should be caused by the subduction of the continental lithosphere. Although it cannot bedetermined whether it comes from India or Eurasia, a continental lithosphere is thrusting northwardsalongthisthrust fault.
(3) The deep process of the normal collision and deformation are different from that of oblique collision. West Kunlun and the Qilian Mts. are both located at the position of collision and deformation, where the lithosphere of the Tarim is subducting southwards. Because West Kunlun is relatively close to the Indian plate, theTarim lithosphere collided with thenorthsubducting Indian lithosphere underWest Kunlun as theformer subducted southwards for a short distance. The Altyn Mts. featuring obliquecollision and deformation constrains the deep subduction of the Tarim crust beneath the Tibetan plateau because of strike-slipping and shearing of the lithosphere. However, in themantlelid, low-anglesouth inclining reflections may reflect that theTarim mantlehasal ready subducted beneath theTibetan plateau and resulted in detachment structure at the bottom of the crust. This may be the deep effect of the oblique collision.

(4) In the west Kunlun-Tarim and Qilian profiles, a thrust deformation zone has developed for about $50 \mathrm{~km}$ from the piedmont to the basins. And in the Altyn-Tarim profile, the deformation zone is about $120 \mathrm{~km}$ in width. This may be related to the angle of subduction and collision. In the Himalayan, the thrust deformation zone is about $200 \mathrm{~km}$ in width (Chen et al. 1999). The Indian plate is subducting along the MBT at a low angle. Therefore, deep processes of the collision deformation are different between the northern margin and southern margin of theTibetan plateau.

\section{References}

Chen WP, CY Chen and JL Nabelek. 1999. Present-day deformation of the Qaidam basin with implications for intra-continental tectonics. Tectonophysics 305: 165-181

Gao R, X Cheng and Q Ding. 1995. Preliminary Geodynamic Model of Golmud—Ejin Qi. Geoscience Transect, Acta Geophysica Sinica (in Chinese) 38 (II): 3-14

Gao R, X Cheng and Q Ding. 1999. Lithospheric structure and geodynamic model of the Golmud-Ejin transect in northern Tibet. Geol. Society of America Special Paper 328: 9-17

Gao R, D Huang and D Lu. 2000. Deep seismic reflection profile across Juncture zone between Tarim basin and west Kunlun Mountain. Science Bulletin 45(17): 1874-1849

Gao R, P Li, Q Li, Y Guan, D Shi, X Kong and H Liu. 2001. Deep process of the collision and deformation on the northern margin of the Tibetan plateau: Revelation from investigation of the deep seismic profiles. Science in China 44(D): 71-78

Kao H, R Gao, RJ Rau, S Danian, R Chen, Y Guan and TW Francis. 2001. Seismic image of the Tarim basin and its collision with Tibet. Geology 29(7): 575-578 